\title{
Recognition and differentiation of species in the Passiflora sidifolia complex
}

\begin{tabular}{|r|l|}
\hline Journal: & Botany \\
\hline Manuscript ID & cjb-2014-0256.R3 \\
\hline Manuscript Type: & Article \\
\hline Date Submitted by the Author: & $13-$ May-2015 \\
\hline Complete List of Authors: & $\begin{array}{l}\text { Nardin, Carla; Instituto Agronômico de Campinas, Centro de Recursos } \\
\text { Genéticos Vegetais } \\
\text { Bernacci, Luís; IAC - Instituto Agronômico, Centro de Recursos Genéticos } \\
\text { Vegetais } \\
\text { Plotze, Rodrigo; Universidade de São Paulo, Instituto de Ciências } \\
\text { Matemáticas e de Computação } \\
\text { Bruno, Odemir Martinez; Universidade de São Paulo, Instituto de Física } \\
\text { Shepherd, George; UNICAMP, Department of Plant Biology }\end{array}$ \\
\hline Keyword: & $\begin{array}{l}\text { Leaf Architecture Working Group, Morphology, Multivariate analysis, } \\
\text { Passifloraceae, Taxonomy }\end{array}$ \\
\hline
\end{tabular}

SCHOLARONE $^{\mathrm{m}}$

Manuscripts 


\section{Recognition and differentiation of species in the Passiflora sidifolia complex}

Carla Fernanda Nardin ${ }^{1}$, Luís Carlos Bernacci, Rodrigo O. Plotze, Odemir M. Bruno, and George J.

Shepherd

C.F. Nardin ${ }^{1}$ and L.C. Bernacci. Instituto Agronômico de Campinas (IAC), Av. Barão de Itapura, 1481 Campinas SP, Brasil CEP 13020-902.

C.F. Nardin

Started as undergraduate research project Fapesp no. 04/14436-6

R.O. Plotze Instituto de Ciências Matemáticas e de Computação, Universidade de São Paulo (ICMC-USP), Av. do Trabalhador São-Carlense, 400 Centro. Cx. Postal 688, São Carlos SP, Brasil CEP 13560-970.

O.M. Bruno Instituto de Física, Universidade de São Paulo, Cx. Postal 369, São Carlos SP, Brasil CEP 13560-970

G.J. Shepherd Prof. Retired. Departamento de Biologia Vegetal - Instituto de Biologia Universidade Estadual de Campinas (UNICAMP), Cidade Universitária "Zeferino Vaz", Distrito de Barão Geraldo, Campinas, SP Brasil CEP 13083-970.

${ }^{1}$ Corresponding author (carlanardin@iac.sp.gov.br) 


\begin{abstract}
The variation in leaf morphology observed in Passifloraceae is one of the most extreme cases in the Angiosperms, allowing some species within this family to be distinguished by their leaves. Nevertheless, other species in this family are difficult to recognize based solely on leaf morphology, or by floral and molecular characteristics. Aiming to verify the similarities and differences between the Passiflora species P. actinia, P. elegans, P. sidifolia and P. watsoniana, detailed analyses were conducted regarding the morphological traits of the leaf blade, specifically, shape and venation, and the flower. The data were composed of continuous and qualitative values, using the Gower coefficient. A Principal Coordinates Analysis (PCoA) and cluster analysis were performed. Features that have not previously been used for the Passifloraceae, such as leaf venation, were important for the distinction of $P$. watsoniana from the other species. The analyses including only the species P. actinia, P. sidifolia and P. elegans showed a clear differentiation between them. Despite the wide variability observed in $P$. elegans, the analysis revealed that the different populations from different regions had more similarities with each other than with any other species.
\end{abstract}

Keywords: Leaf Architecture Working Group, Morphology, Multivariate analysis, Passifloraceae, Taxonomy 


\section{Introduction}

The Passifloraceae have economic importance in the medical and ornamental sector, and especially as a food source (passion fruit). The areas of greatest diversity of Passifloraceae are found in the countries of Brazil and Colombia (Killip 1938). In addition to economic interest, the family has a fundamental ecological importance, and the diversity of its species deserves attention.

The Passifloraceae distribution is essentially pantropical with a few temperate species in North and South America, southern China, and New Zealand and is represented by 17 genera and 700-750 species (Feuillet and MacDougal 2007). According to current records, there are about 500 species occurring in the Neotropics (Feuillet and MacDougal 2007), with 4 genera and approximately 150 species found in Brazil (Bernacci et al. 2015). The genus, Passiflora, is the largest in the Passifloraceae, with more than 560 species (Krosnick et al. 2013).

Knowledge of the taxonomy and distribution of the Brazilian Passifloraceae species has greatly increased in recent years due to new collecting programs. For example, in the last two decades, the number of species recorded in São Paulo State has increased by 33\% (15 species) (Bernacci et al. 2003; Bernacci et al. 2011) when compared to the previous records for the family in the state (Killip 1938; Cervi 1997). This new information on the distributions of the species in São Paulo State indicated that four species $(10 \%$ of the species) are endangered (Environment Secretariat 2004), and further studies are needed to facilitate the identification and recognition of other species (from the Passiflora elegans group and from subgenus Astrophea - Bernacci et al. 2003).

From the time when Linnaeus established the foundations of taxonomy, around the year 1753, the identification and reconstruction of relationships between plants have largely been based on the characteristics of the reproductive organs (Leaf Architecture Working Group 1999). For the identification of Passifloraceae species, the analyses focus on floral morphology (Masters 1872; Killip 1938; Sacco 1980; Escobar 1988; Holm-Nielsen et al. 1988; Cervi 1997; Nunes and Queiroz 2001; Bernacci et al. 2003). In addition to the reproductive morphology (especially flowers and 
bracts), vegetative morphology (especially leaf blade and stipules) has been described as the most diverse of any of the families of Angiosperms (MacDougal 1994). In some cases, it is possible to distinguish species by leaf morphology alone, as is the case of Passiflora cirrhiflora Juss., a species from the Amazon region (Ribeiro et al. 1999). However, for other species, the differences between them, including molecular differences (Pádua 2004), are not so pronounced, making the correct identification of these species more difficult.

The subjectivity and lack of precision in traditional taxonomy has been cited as one of the difficulties in the recognition of taxonomy as a science, but there is still a need for more information and knowledge of plant biodiversity (Rapini 2004). However, more updated techniques, such as the utilization of DNA information, are not necessarily a more suitable option for the recognition of species (Rapini 2004). Since the first comprehensive terminology for leaf architecture by Ettinghausen (1861 in Spicer 1986), a number of new terminologies for the different aspects of leaf morphology have been developed (Hickey 1973, 1979 in Spicer 1986). These terminologies have been used, at least in part, by many researchers (Spicer 1986). More detailed morphological analyses, including descriptions of leaf shape and venation, have been used to distinguish species that are difficult to recognize (Baumgratz and Ferreira 1980; Leaf Architecture Working Group 1999; Cardoso and Sajo 2004, 2006). With the use of a new computational morphometric method, leaf traits, such as leaf shape and venation, have been used to enable the distinction of Passifloraceae species (Plotze et al. 2005).

The delimitation and classification of the species Passiflora actinia Hook., P. elegans Mast., P. sidifolia M.Roem., and P. watsoniana Mast. differ between authors. Although P. actinia and $P$. sidifolia are treated as distinct from each other (Killip 1938; Cervi 1997; Bernacci et al. 2003), their similarities have long been noted (Killip 1938). On the other hand, the species that was referred to as P. watsoniana, in São Paulo State (Cervi 1997), was later questioned (Bernacci et al. 2003), and the materials were identified as $P$. elegans. Recently, the use of the species name $P$. elegans, instead of P. watsoniana, has become more widely accepted in São Paulo (Bernacci et al. 2011). Species 
recognized as currently belonging to the $P$. sidifolia complex (P. actinia, P. elegans and $P$. sidifolia) were previously classified in different series. Formally, P. actinia was classified in the series Simplicifoliae, while P. elegans was classified in the series Lobatae, and P. sidifolia in the series Imbricatae (Killip 1938; Cervi 1997). Recently, these three species were all placed in the section Granadillastrum (Feuillet and MacDougal 2003). Passiflora watsoniana was classified in the series Kermesinae (Killip 1938; Cervi 1997), and more recently, in the section Kermesinae (Feuillet and MacDougal 2003). However, these were artificial series, since they were based on few features. Macromolecular analysis reinforces the distinction of Passiflora actinia and P. elegans, with only a single hybrid specimen observed between them (Lorenz Lemke et al. 2005).

In the present study, we performed multivariate analyses from detailed morphological surveys, especially leaf shape and venation. Our objective was to identify and separate the species in the Passiflora sidifolia complex (P. actinia, P. elegans and P. sidifolia), and to distinguish these species from $P$. watsoniana, thus contributing to a more profound understanding the taxonomy of these species in São Paulo and other Brazilian states.

We hypothesized that although reproductive structures are traditionally used to distinguish Passiflora species in the P. sidifolia complex (P. actinia, P. elegans and P. sidifolia), vegetative characteristics, such as leaf venation patterns, that have yet not been used, may be useful, especially with sterile material. Thus, our objective was to recognize which vegetative characteristics are meaningful to distinguish the species of this group.

\section{Materials and methods}

Study Species

The species Passiflora actinia, P. elegans, and P. sidifolia were studied; all three are recognized in this study as belonging informally to the $P$. sidifolia complex, but the distinction between them is controversial. For the initial analyses, in addition to the above-mentioned species, 
the species $P$. watsoniana was included, also belonging to the subgenus Passiflora. The occurrence of this species was recorded in the state of São Paulo, but its identity was later questioned.

Passiflora actinia always has entire leaves, whereas $P$. sidifolia can have entire or lobed leaves. Passiflora sidifolia is distinguished from the other species in this study by its much smaller bract size. Passiflora watsoniana is distinguishable from the other three species by its nonverticillate bracts.

The distribution of $P$. actinia extends from the state of Espírito Santo to Rio Grande do Sul; P. sidifolia occurs in the states of Rio de Janeiro, Minas Gerais, and São Paulo (Bernacci et al. 2003); and P. elegans in the states of Santa Catarina and Rio Grande do Sul, but is also found in Argentina and Uruguay (Cervi 1997). The distribution of P. elegans has recently been extended to the states of Minas Gerais and São Paulo, but some morphological differences have been observed, which are potentially related to this area of distribution. Because of these morphological differences, the identification of $P$. elegans in these new areas has been questioned (Bernacci et al. 2003). The distribution of $P$. watsoniana has long been unclear. The type material mentions a general distribution in the southeastern or central-western regions of Brazil. However, this material not only lacks the name of the collector, but it came from a plant that was cultivated in Kew [Royal Botanic Gardens], which makes the record of origin questionable (Killip 1938; Cervi 1997). The occurrence of this species was later recorded in states of Paraíba and Pernambuco, in the northeastern region of Brazil, and also in the states of Minas Gerais and São Paulo, southeastern regions of Brazil (Cervi 1997); however, the occurrence in São Paulo (Bernacci et al. 2003) was discarded and treated as misidentification (Bernacci et al., 2003). Although not very abundant, herbarium records were used by Giovanni (2011) to create potential distribution models. These indicate that $P$. watsoniana would occur in a relatively extensive continuous area. The models suggested a concentrated distribution in the northeastern region of Brazil, extending from the state of Rio Grande do Norte down to the state of Rio de Janeiro, in the Southeast. The model also indicated disjoint occurrences in Ceará (Northeast), Amazônia (North), central-western and 
southern regions of Brazil, but did not indicate any potential occurrence in São Paulo State (Bernacci and Giovanni 2012).

\section{Measurements of morphological characteristics}

The analyses were based on herbarium material from the IAC (Agronomic Institute of Campinas, São Paulo, Brazil) and other herbaria. We adopted a numerical scale for each characteristic analyzed, corresponding to the quantity of types observed, and followed Radford et al. (1974) for the morphological patterns for the shape of the leaf blade.

The morphological traits of 51 P. elegans voucher specimens were measured, six being from the South Coast of São Paulo, eight from the North Coast of São Paulo, and 37 from Rio Grande do Sul. Thirty-two vouchers of $P$. sidifolia, 22 of $P$. actinia, and five of $P$. watsoniana were also analyzed (supplementary table S1). The goal was to sample the intra and interspecific variability, especially with regards to the leaf variability found in $P$. sidifolia, which usually has a lobed blade, but may also have an entire blade. Three leaf blades from a total of 110 herbarium specimens were analyzed, resulting in 324 sets of observations.

\section{Clearing, staining and description of leaf blade}

Twenty-four leaf blades of $P$. elegans were cleared and stained (adapted from Shobe and Lersten 1967), nine were from materials originating from the South Coast of São Paulo (Guarujá and Juréia - SP), 10 from the North Coast of São Paulo (Ubatuba, Cunha, Caraguatatuba and São Sebastião - SP) and five from Rio Grande do Sul. We also analyzed 13 leaf blades from P. sidifolia, six from $P$. actinia and two from $P$. watsoniana, whose shape and venation are described herein in detail (according to Leaf Architecture Working Group 1999).

Data analysis 
In total, 34 traits were initially analyzed, including those of leaf venation, with 21 continuous (Table 1), five multistate, and eight binary (Table 2). Some traits were excluded, because they did not differ between the species. Therefore, 29 traits were selected for the analysis of the $P$. sidifolia complex, with 21 continuous, four multistate, and four binary. For a final analysis, we used only $P$. elegans specimens that had been collected from three different regions. The qualitative variable "smaller bract" was excluded from this analysis, since it is invariant for this species. Thus, a total of 28 characters were analyzed.

Due to the heterogeneous data matrix with continuous, binary and qualitative data, the Gower coefficient was used for carrying out the Principal Coordinates Analysis (PCoA - Legendre and Legendre 2012) and the cluster analysis (Weighted Average - WPGMA was adopted as the clustering method due to differing of samples for each species), with the aid of the FITOPAC program, version 2.1.2 (Shepherd 2010). The goal was to verify the similarities and distinctions between species, and in P. elegans investigate infraspecific variation among regions. Electronic Supplementary Material with representations of three-dimensional graphics is available as an additional resource (ParallelGraphics 1999). The PCoA analysis was carried out in three steps: 1) with all four species, 2) excluding $P$. watsoniana, and 3) only $P$. elegans from different regions.

Comparison of the eigenvalues obtained with the values expected from the "Broken-Stick" model was used to assess the significance of the first axes (Joliffe 2002; Cangelosi and Goriely 2007).

\section{Results}

In all of the PCoA analyses, the variance explained was greater than that predicted by the broken-stick model for at least the first five axes. This criterion is rather conservative since the model tends to produce higher variances in the first axes than are usually observed in genuinely random matrices (Cangelosi and Goriely 2007; Shepherd 2015 - unpublished data). However, we 
rarely used more than two or three axes, since each axis represents a particular gradient, and it is difficult to interpret a system with more than three gradients (Gotelli and Ellison 2011).

In the first analysis, with the PCoA involving all four species, axis 1 was responsible for $16.30 \%$, axis 2 for $14.88 \%$ and axis 3 for $8.48 \%$ of the variance explained, giving a total of $39.66 \%$ of the variance observed in the first three axes. By means of axes 1 and 2 of the PCoA it was possible to observe some separation of the species, and also by means of axes 1 and 3 (Fig. 1). Axes 2 and 3 show a complete separation of $P$. watsoniana from the other species, mainly due to axis 3 . The characteristics that had the highest correlation with the first axis were shape of the leaf blade (0.86), the apex type of lateral lobes $(0.81)$ and the shape of the apex of the leaf blade $(0.75)$; the characteristics having the highest correlation with the second axis were the width of the larger bracts $(0.71)$ and the bract shape (0.71), and the length of the medial lobe of the leaf blade $(0.70)$; and the characteristics having the highest correlation with the third axis were type of operculum (0.84), the type and position of the bracts, fifth vein category, highest order and highest excurrent of leaf blade (0.82).

In $P$. watsoniana, the fifth vein category has a dichotomous pattern, as opposed to a regular polygonal reticulate pattern found in the other species, and also shows a higher order and higher excurrent extension with smaller values ( 5 and 4 , respectively - Table 2).

It was not possible to view a complete separation between the species of the P. sidifolia complex in the initial analyses. This may be due to the addition of $P$. watsoniana (clearly a separate and distinct taxon and thus an outlier when compared with the remaining species), which may have displaced the direction and the center of the axes in relation to these species. The resulting axes may not be ideal for showing the maximum variance of the remaining species. Thus, in order to analyze the position of each species within the Passiflora sidifolia complex, another analysis was carried out exclusively with the species from this complex (Fig. 3).

In the second analysis, which excluded P. watsoniana, the first three axes of the PCoA represented $39.1 \%$ of the total variation observed, in which axis 1 was responsible for $22.51 \%$, axis 
2 for $9.38 \%$ and axis 3 for $7.21 \%$ of the total variance explained. The characteristics that had the highest correlation with the first axis were the shape of the leaf blade (0.93), the apex type of lateral lobes (0.80), and apex shape of the leaf blade (0.78); the characteristics that had the highest correlation with the second axis were the length of the medial lobe $(0.80)$, the shape of the bracts (0.78), and width of larger bracts (0.77); and the characteristics having the highest correlation with the third axis were the width of the leaf blade $(0.75)$, length of stipules $(0.66)$, and presence of smaller bract (0.60). The first two axes (Fig. 3) show a clear distinction between Passiflora actinia 1; Passiflora sidifolia - 2 and Passiflora elegans - 3. There was also a clear distinction between the different sample regions of $P$. elegans, but there is a slight overlap between them. Axes 1 and 3 indicated some overlap between $P$. actinia and $P$. sidifolia, and also between all material from the North Coast and South Coast of São Paulo. Axes 2 and 3 placed P. actinia and P. sidifolia at the extremes of axis 2, but showed some overlap between these two species and P. elegans. Axis 3 did not improve the distinction between species or specimens of $P$. elegans from different regions.

The dendrogram showed a clear distinction between the species of the Passiflora sidifolia complex (Fig. 4), with a cophenetic correlation of 0.83 , indicating a good fit of the dendrogram to the distance matrices. The first group (1) was composed of the species $P$. sidifolia, where the smaller bract was the main variable that distinguished it from all other species. Group 2 was composed only of materials from $P$. actinia.

Lastly, in the dendrogram (Fig. 4), the third group (3) corresponds to P. elegans. There is an obvious distinction between the three different regions: Rio Grande do Sul (RS), the South Coast, and North Coast of São Paulo, but there were five samples from the North Coast of São Paulo that fell into the group from Rio Grande do Sul.

In the third PCoA, only with P. elegans, when considering axes 1 and 2 (Fig. 5 and supplementary video S1), the sample material from the South Coast of São Paulo (b) and Rio Grande do Sul (a) appeared close to each other, but there was an obvious separation of the materials from the North Coast of São Paulo (c). This suggests a possible gradual change in traits from south to north. 
However, this gradation was only observed with axis 1 versus axis 2 . When evaluating axes 1 and 3 (Fig. 6) or 2 and 3, the material from the South Coast of São Paulo (b) appeared to be separated from the material from both Rio Grande do Sul (a) and the North Coast of São Paulo (c), which appeared closer together. For axes 2 and 3, the P. elegans material from Rio Grande do Sul were found to be in an intermediate position between the South Coast and North Coast of São Paulo.

The variables most correlated with the $P$. elegans PCoA for axis 1 were the length of the lateral lobe of the leaf blade (0.90), width (0.81) and length of the petiole glands, and diameter of the petiole (0.71); the variables most correlated with axis 2 were the apex type of lateral lobe of the leaf blade (0.83), the length of stipules (0.78) and the joined portion of the leaf blade (0.66); and the most correlated variables for axis 3 were the shape of the bracts and length of leaf blade (0.77) and length of smaller bract and width of the leaf blade (0.50).

Some characteristics were exclusive to material of $P$. elegans from different regions. For example, the base of the operculum found in specimens from the South Coast of São Paulo was membranous and plicate, but the rest of the operculum was filamentous; the operculum found in the other two regions were entirely membranous plicate. The specimens from the North Coast of São Paulo exhibited an exclusive characteristic in relation to leaf shape, which was circular, while the remaining specimens had leaf shapes that were very widely ovate, oblate (exclusively in the material from Rio Grande do Sul) and transversely elliptic (exclusively in the material from the South Coast of São Paulo). In general, for most traits studied, the differences in material assigned to $P$. elegans from different areas were less conspicuous and / or diffuse.

Based on the morphological characteristics analyzed, it was possible to discern some important characteristics that have not previously been used in the differentiation of the study species. They have been incorporated into the following dichotomous key to facilitate the distinction and recognition of species in the $P$. sidifolia complex, as well as in relation to $P$. watsoniana. 
1 - Bracts alternate and setaceous, fifth vein category dichotomous, highest order equal five and highest excurrent equal four P. watsoniana Mast.

1 - Bracts verticillate and foliaceous, fifth vein category regular polygonal reticulate, highest order equal six and highest excurrent equal five 2

2 - Bracts widely elliptic, with one much smaller than the other two P. sidifolia M.Roem.

2' - Bracts usually ovate and all three of similar size 3

3 - Leaves always entire (never lobed), elliptic or ovate, apex usually convex, rarely straight or round P. actinia Hook. 3' - Leaves always with three lobes, widely ovate to transversely elliptic, usually round, rarely convex P. elegans Mast.

\section{Discussion}

The complete separation of $P$. watsoniana from the other species provides evidence to support the concept that $P$. actinia, $P$. elegans and $P$. sidifolia belong to a single complex within the section Granadillastrum Tr. \& Planch., and provide further evidence for the segregation of $P$. watsoniana into the section Kermesinae (Cervi 1997), as it is defined in the most current taxonomic proposal (Feuillet and MacDougal 2003). Furthermore, our results support the interpretations of Bernacci et al. (2003), which states that the herbarium specimen Silva et al. 175 (herbarium SP), originally identified as $P$. watsoniana, is most likely P. elegans, and that $P$. watsoniana is not native to the state of São Paulo. One of the more distinctive traits found in the species from the section Granadillastrum is the arrangement of bracts in a verticillate pattern, as opposed to the alternating bracts found in species from the section Kermesinae (Killip 1938; Feuillet and MacDougal 2003).

Venation is a trait that has not been previously used in the taxonomy of Passifloraceae. However, we found it to be an important feature in the differentiation of $P$. watsoniana from the 
other three species in this study (Fig. 2). There is evidence that it is a promising trait in terms of differentiating between species belonging to different subgenera, and has been indicated as an additional feature contributing to recognition at this level (unpublished data).

Although they have been treated as belonging to different series, P. actinia in the series Simplicifoliae (Harms) Killip, P. elegans in the series Lobatae (Harms) Killip, and P. sidifolia in the series Imbricatae Killip ex Cervi (Killip 1938; Cervi 1997) all have the same leaf venation patterns and very similar flowers, which have oblong petals and sepals, a rounded apex that is white in color, and a corona in two series, white striped with lilac-blue at the apex and vinaceous-red at the base. Also, the branches of these species are smooth and cylindrical, and have a pale green color. The leaves also show similarities. They are glabrous, pale green in color and, on average, range between 4-6 cm in length and 4-5 cm in width. Passiflora actinia has entire leaves, without lobes, while the two other species have leaves that are normally lobed, except in some cases where P. sidifolia is found to have entire leaves. In P. elegans, the length / width ratio is smaller than 1, and for the other two species the value is greater than 1 . While the species differ between them in various characteristics, there is still interspecific overlap in the characteristics of these species, which makes it even more difficult to differentiate them, especially by people who are not familiar with this species complex.

The intraspecific plasticity of leaf blades was limited except for $P$. sidifolia. Therefore, leaf shape is not a good feature to distinguish between $P$. sidifolia and $P$. actinia, since some individuals of $P$. sidifolia have either entire and lobed leaves and / or asymmetrically lobed leaves (such as GF Árbocz 1425 - IAC 32344; A Custódio Filho 376 - SP-168234 and R. Simão-Bianchini 688 - IAC 33735). Individuals of P. sidifolia with exclusively entire leaves have been identified (A.O. Scariot 371 - IAC 34272, SPF 82174; J.G. Kuhlmann without number - RB 110640), but the majority of individuals have lobed leaves. Passiflora sidifolia has bracts of two different sizes; smaller bracts and bracts that are widely elliptic and larger in size $(2.5-5.5 \times 2-4.5 \mathrm{~cm}$ for the two larger bracts and 
$1.5-4.2 \times 1.5-3.2 \mathrm{~cm}$ for the smaller bract), while P. actinia has bracts that are ovate and smaller $(1.5-3 \times 0.6-2 \mathrm{~cm})$.

In addition to always having a lobed leaf, the shape of the leaf blade (widely ovate, very widely ovate, circular, oblate or transversely elliptic), the leaf apex (usually rounded, rarely convex) and blade size $(2-7.9 \times 2.3-7.3 \mathrm{~cm})$ found in $P$. elegans revealed themselves to be features that distinguish it from P. actinia (blade $3-8.9 \times 2.4-7.8 \mathrm{~cm}$, elliptic or ovate, apex usually convex, rarely straight or round).

The occurrence of P. elegans has recently been recorded in the state of São Paulo (Bernacci et al. 2003). In the past, this species was thought to occur only in the state of Rio Grande do Sul. A sample of this species collected in the state of Santa Catarina was believed to have possibly originated from cultivation (Cervi 1997). Although a hybrid between P. elegans and P. actinia has been observed in Rio Grande do Sul, these two species would not be sympatric, since they occur in different environments (Lorenz-Lemke et al. 2005). In Rio Grande do Sul, P. actinia is found to occur in the Atlantic Forests, in the coastal region, but $P$. elegans occurs only in riparian forests in the inland region of the state. However, with periods of contraction and expansion of the Atlantic Forest that have occurred in the last 20000 years, the distribution of these species may now be overlapping (Lorenz-Lemke et al. 2005). The discovery of P. elegans in São Paulo suggests that its occurrence in Santa Catarina is natural, and did not originate from cultivation. This is also an indication that the distribution of this species may be more extensive than previously believed.

Despite the extensive variability observed in $P$. elegans, the analyses indicated that the populations from different regions still present more similarities with each other than with any other species. Our results, which show an association between the distribution and morphological patterns in $P$. elegans, and the possibility of hybrids with other species in the complex (P. actinia), as indicated by Lorenz-Lemke et al. (2005) call for detailed studies for the P. sidifolia complex.

The variability observed in P. elegans was found to be similar within each group of materials from each area, although the number of specimens sampled from each regions was different. The 
North Coast (8) and South Coast (7) of São Paulo had much smaller samples than Rio Grande do Sul (37).

Our results provide evidence of the morphological differences in the materials assigned to P. elegans, but a more in-depth assessment of this variation with regards to spatial distribution is required. Until recently, only a small number of specimens assigned to P. elegans had been available for analysis in the state of São Paulo. Passiflora elegans was believed to occur only in Rio Grande do Sul, Uruguay and Argentina, with a single record for Santa Catarina, near the city of Itajaí (Cervi 1997). Subsequently, in addition to this sample from Itajaí, another was found in Ilha Campeche (Florianópolis, SC - Cervi, personal communication), and there are records that are reported to be from Ilha de Santa Catarina (SpeciesLink - http://www.splink.org.br/index?lang=pt). However, there is currently no record in the state of Paraná, which lies between Santa Catarina and São Paulo. This may be a result of lack of sampling or evidence of disjunct distribution.

To resolve the status of the variants found in different populations of P.elegans, an intensive collecting program with emphasis on the states of São Paulo, Paraná and Santa Catarina is needed to verify the distribution of this species and to obtain more representative samples in the areas with only few specimens available. Additional analyses using molecular, genetic and palinological data, among others, for material from these three different regions may help discern subspecies or species among the material presently assigned to P. elegans.

We believe that the analysis method and the use of multivariate analyses, not only enabled a more appropriate recognition of species, but also allowed us to observe the relationships between traits. With regard to the analysis tools, our results reinforce the effectiveness of PCoA. Similar results were observed in a study where researchers used 61 morphological characteristics of the family Zygophyllaceae to perform PCoA, allowing the identification of six main groups of species in this family (Khalik 2012).

In summary, we found within the subgenus Passiflora, the species P. sidifolia, P. actinia, and P. elegans form a complex and have strong similarities between them. We also found $P$. watsoniana 
to be very distinct from these other three taxa, and further evidence indicating that this species does not occur as a native in the state of São Paulo. Despite the strong similarities among the species of the $P$. sidifolia complex, we were able to identify possible distinctions between them. We also identified some differential characteristics for P. elegans from different regions, which may represent distinct taxonomic entities of this species.

We emphasize the importance of morphological characteristics in the distinction between these species, and between P. elegans from different regions where it occurs in Brazil. We also discuss features that have not previously been utilized for such distinctions, such as the pattern of the fifth vein category, highest order and highest vein order showing excurrent branching (Leaf Architecture Working Group 1999). In some cases, a more in-depth and enhanced description of the structures, as in the case of the operculum in P. elegans, can contribute to identification. Finally, we highlighted the relevance of some traits that are already used, such as the presence of a bract that is characteristically smaller in P. sidifolia, and that other features, such as the length of leaf junction, length and width of medial and lateral lobes of the leaf were not suitable for the characterization of this species.

Acknowledgments To FAPESP (Fundação de Amparo a Pesquisa do Estado de Sao Paulo), for providing a scientific initiation scholarship to C.F. Nardin (04/14436-6), in the period of 20052006; to the curators of the herbarium IAC, for the use of infrastructure and herbaria ALCB, BHCB, CEPEC, CESJ, ESA, FUEL, GUA, HPL, IAC, ICN, MAC, MBM, MBML, PACA, R, RB, RFA, RUSU, SP, SPF, UB e UEC, for loans of herbarium specimens for analysis; to curators of passion fruit gene banks from IAC and Plantarum Institute, for supplying fresh materials for analysis; to PqC Rachel B. Queiroz Voltan (IAC) for assistance in the procedures in clearing and staining of leaf blades; to Dr. Leonardo Meireles, for the previous reading of the manuscript and suggestions, and to Rebecca Fletcher for reviewing the English. 


\section{References}

Backeljau, T., Breugelmans, K., De Wolf, H., Geenen, S., Harrier, L.A., Jordaens, K., Van Riel, P., and Winnepenninckx, B. 2000. Software dependent phenetic relationships of non-nodulating African species of Acacia. Plant Systematics and Evolution 220: 139-146. doi:10.1007/BF00985042.

Baumgratz, J.F.A., Ferreira, G.L. 1980. Estudo da nervação e epiderme foliar das Melastomataceae do município do Rio de Janeiro. Gênero Miconia. Seção Miconia. Rodriguésia 32(54): 161169.

Bernacci, L.C., Vitta, F.A., and Bakker, Y.V. 2003 Passiflora. In Flora Fanerogâmica do Estado de São Paulo. Edited by M.G.L. Wanderley, G.J. Shepherd, A.M. Giulietti, and T.S. Melhem. RiMa/FAPESP, São Paulo,vol. 3, pp 248-271.

Bernacci, L.C., Cervi, A.C., and Milward-de-Azevedo, M.A. 2011. Checklist das Spermatophyta do Estado de São Paulo, Brasil: Passifloraceae. Biota Neotrop. 11(11a): 337-338.

Bernacci, L.C., and Giovanni, R. 2012. Passiflora watsoniana (32943). In Biogeografia da Flora e Fungos do Brasil. INCT Herbário Virtual. Available from http://biogeo.inct.florabrasil.net/txn/32943 [accessed 02 December 2013].

Bernacci, L.C., Cervi, A.C., Milward-de-Azevedo, M.A., Nunes, T.S., Imig, D.C. and Mezzonato, A.C. 2015. Passifloraceae. In Lista de Espécies da Flora do Brasil. Jardim Botânico do Rio $\begin{array}{lll}\text { de } & \text { Janeiro. } & \text { Available }\end{array}$ http://floradobrasil.jbrj.gov.br/jabot/listaBrasil/PrincipalUC/PrincipalUC.do?lingua=en [accessed 19 February 2015].

Cangelosi, R. and Goriely, A. 2007. Component retention in principal component analysis with application to cDNA microarray data. Biology Direct 2:2. doi: 10.1186/1745-6150-2-2.

Cardoso, C.M.V., and Sajo, M.G. 2004. Vascularização foliar e a identificação de espécies de Eugenia L. (Myrtaceae) da bacia hidrográfica do Rio Tibagi, PR. Revista Brasileira de Botânica. 27(1): 47-54. 
Cardoso, C.M.V., and Sajo, M.G. 2006. Nervação foliar em espécies brasileiras de Myrtaceae Adans. Acta Botanica Brasilica 20(3): 657-669.

Cervi, A.C. 1997. Passifloraceae do Brasil: estudo do gênero Passiflora L., subgênero Passiflora. FontQueria 45:1-92

Curi, P.R. 1983. Análise de agrupamento: métodos seqüênciais, aglomerativos e hierárquicos. Ciência e Cultura 35: 1416-1429.

Environment Secretariat 2004. Espécies da flora ameaçadas de extinção no Estado de São Paulo. [online]. Resolução SMA 48. Diário Oficial do Estado. Available from http://licenciamento.cetesb.sp.gov.br/legislacao/estadual/resolucoes/2004_Res_SMA_48.pdf [accessed 02 December 2013].

Escobar, L. 1988. Passifloraceae: Passiflora subgêneros Tacsonia, Rathea, Manicata and Distephana. Flora de Colombia 10: 1-138.

Feuillet, C., and MacDougal, J.M. 2003. A new infrageneric classification of Passiflora L. (Passifloraceae). Passiflora 13(2) :34-35 and 37-38.

Feuillet, C., and MacDougal, J.M. 2007. Passifloraceae. In The families and genera of vascular plants, vol. 9, Edited by K. Kubitzki, Berlin, Springer. pp. 270 -281.

Gengler-Nowak, K. 2002. Phenetic analyses of morphological traits in the Malesherbia humilis complex (Malesherbiaceae). Taxon 51: 281-293.

Giovanni, R. 2011. Uso de modelagem de nicho ecológico em conservação de espécies de Passifloraceae no Estado de São Paulo. M.Sc thesis. ESCAS - Escola Superior de Conservação Ambiental e Sustentabilidade, São Paulo, Brasil.

Gotelli, N.J., and Ellison, A.M. 2011. Princípios de estatística em ecologia. Artmed, Santana.

Holm-Nielsen, L.B., Jørgensen, P.M., and Lawesson, J.E. 1988. Passifloraceae. In Harling G, Andersson L (eds) Flora of Ecuador 31: 1-130.

Inácio, P., Lewinsohn, T., Carmo, R.L., and Hogan, D.J. 2002. Ordenação multivariada na ecologia e seu uso em ciências ambientais. Ambiente \& Sociedade 10: 69-83. 
Joliffe, I.T. 2002. Principal component analysis. (ed. 2). Springer - Verlag, New York.

Khalik, K.N.A. 2012. A numerical taxonomic study of the family Zygophyllaceae from Egypt. Acta Botanica Brasilica 26(1):165-180.

Killip, E.P. 1938. The American species of Passifloraceae. Botanical Series 49, Field Museum of Natural History, Chicago.

Krosnick, S.E., Porter-Utley, K., Jørgensen, P., and McDade, L. 2013. New Insights into the Evolution of Passiflora subgenus Decaloba (Passifloraceae): Phylogenetic Relationships and Morphological Synapomorphies. Systematic Botany 38(3): 692-713.

Leaf Architecture Working Group. 1999. Manual of leaf architecture: morphological description and categorization of dicotyledonous and net-veined monocotyledonous angiosperms. Smithsonian Institution, Washington.

Legendre, P., and Legendre, L. 2012. Numerical Ecology, Third Edition, Elsevier.

Lorenz-Lemke, A.P., Muschner, V., Bonatto, S., Cervi, A.C., Salzano, F.M., and Freitas, L.B. 2005. Phylogeographic inferences concerning evolution of brazilian Passiflora actinia and $P$. elegans (Passifloraceae) based on ITS (nrDNA) variation. Annals of Botany 95: 799-806. doi:10.1093/aob/mci079.

MacDougal, J.M. 1994. Revision of Passiflora subgenus Decaloba section Pseudodysosmia (Passifloraceae). Systematic Botany Monographs 41: 1-146.

Masters, M.T. 1872. Passifloraceae. In Flora Brasiliensis. Edited by C.F.P. Martius, A.G. Eichler and I. Urban. 13:527-628.

Nunes, T.S., and Queiroz, L.P. 2001. A família Passifloraceae na Chapada Diamantina, Bahia, Brasil. Sitientibus ser. Ci. Biol. 1(1):33-46.

Pádua, J.G. 2004. Análises genéticas de espécies do gênero Passiflora L. com base em abordagens filogenéticas, morfométricas e em marcadores microssatélites. PhD Thesis, ESALQ-USP, Piracicaba, São Paulo, Brasil. 
Parallelgraphics. 1999. Cortona3D Viewer User's Guide [online]. Available from http://www.cortona3d.com/system/files/125/original/cortona3d_viewer_user_guide-pdf.pdf [accessed 02 December 2013].

Pereira, J.R.G. 1993. Um estudo sobre alguns métodos hierárquicos para análise de agrupamentos. M.Sc. thesis, Institute of Mathematics, Statistics and Scientific Computation, Unicamp, Campinas, Brasil

Plotze, R.O., Falvo, M., Pádua, J.G., Bernacci, L.C., Vieira, M.L.C., Oliveira, G.C.X., and Bruno, O.M. 2005. Leaf shape analysis using the multiscale Minkowski fractal dimension, a new morphometric method: a study with Passiflora (Passifloraceae). Can. J. Bot. 83: 287-301. doi: 10.1139/b05-002.

Radford, A.E., Dickison, W.C., Massey, J.R., and Bell, C.R. 1974. Vascular Plant Systematics. Harper \& Row, New York.

Rapini, A. 2004. Modernizando a taxonomia. Biota Neotropica 4(1). Available from http://www.biotaneotropica.org.br/v4n1/en/fullpaper?bn00204012004+pt [accessed 02 December 2013].

Ribeiro, J.E.L.S., Hopkins, M.J.G., Vicentini, A., Sothers, C.A., Costa, M.A.S., Brito, J.M., Souza, M.A.D., Martins, L.H.P., Lohmann, L.G., Assunção, P.A.C.L., Pereira, E.C., Silva, C.F., Mesquita, M.R., and Procópio, L.C. 1999. Flora da Reserva Ducke: guia de identificação das plantas vasculares de uma floresta de terra-firme na Amazônia Central. INPA, Manaus, Brasil.

Sacco, J.C. 1980 Passifloráceas. In Flora Ilustrada Catarinense. Edited by R. Reitz. Herbário Barbosa Rodrigues, Itajaí, Brasil

Shepherd, G.J. 2010. Fitopac File Version 2.1.2.85. UNICAMP, Campinas, Brasil

Shobe, W.R., and Lersten, N.R. 1967. A technique for clearing and staining gymnosperm leaves. Botanical Gazette 127(2): 150-152. 
Spicer, R.A. 1986. Pectinal veins: a new concept in terminology for the description of dicotyledonous leaf venation patterns. Botanical Journal of the Linnean Society 93: 379-388.

Souza, V.C., and Lorenzi, H. 2005. Botânica Sistemática: guia ilustrado para identificação das famílias de Angiospermas da flora brasileira, baseado em APG II, Instituto Plantarum, Nova Odessa, Brasil. 


\section{TABLE CAPTIONS}

Table 1 Minimum and maximum values of the continuous characteristics used in the analysis of the group of Passiflora species.

Table 2 Minimum and maximum values of the multistate and binary characteristics used in the analysis of the group of Passiflora species. 


\section{FIGURES CAPTIONS}

Figure 1 Principal Coordinates Analysis (PCoA) using Gower coefficient and 46 variables showing the distinction between species of the $P$. sidifolia complex $(\mathbf{1}$ - P. actinia Hook., P. elegans Mast. and P. sidifolia M.Roem.) and P. watsoniana Mast (2). Numbers in parentheses on the axes correspond to percentage of variance.

Figure 2 Morphology and venation of leaf blade. A. Passiflora actinia Hook.; B. P. sidifolia M.Roem., C-E. P. elegans Mast. (C. Rio Grande do Sul, D. South Coast of São Paulo state, E. North Coast of São Paulo state) F. P. watsoniana Mast.

Figure 3 Principal Coordinates Analysis (PCoA) using Gower coefficient and 29 variables of $P$. elegans Mast. (3) (a - RS; b - South Coast of São Paulo state; and c - North Coast of São Paulo state), and of the Passiflora sidifolia complex (1. Passiflora actinia Hook., 2. Passiflora sidifolia M.Roem.). Numbers in parentheses on the axes correspond to percentage of variance.

Figure 4 Dendrogram using WPGMA method showing the clusters formed of the Passiflora sidifolia complex (1 - P. sidifolia M.Roem.; 2 - P. actinia Hook.; and 3 - P. elegans Mast.).

Figure 5 Axes 1 and 2 of the Principal Coordinates Analysis (PCoA) using Gower coefficient and 28 variables showing infraspecific variation of Passiflora elegans Mast. (a - Rio Grande do Sul, b South Coast of São Paulo state and c- North Coast of São Paulo state). Numbers in parentheses on the axes correspond to percentage of variance.

Figure 6 Axes 1 and 3 of the Principal Coordinates Analysis (PCoA) using Gower coefficient and 28 variables showing infraspecific variation of Passiflora elegans Mast. (a - Rio Grande do Sul, b - 
South Coast of São Paulo state and c- North Coast of São Paulo state). Numbers in parentheses on the axes correspond to percentage of variance. 
Table 1 Minimum and maximum values of the continuous characteristics used in the morphological analysis of Passiflora species.

\begin{tabular}{|c|c|c|c|c|}
\hline $\mathbf{N}^{\mathbf{0}}$ & Characteristics & Minimum & Maximum & Unit \\
\hline 1 & Angle between the main veins of the leaf blade & $\overline{14}$ & 65 & degree \\
\hline 2 & Diameter of the petiole & 0.03 & 0.12 & $\mathrm{~cm}$ \\
\hline 3 & Length of stipule & 0.5 & 3 & $\mathrm{~cm}$ \\
\hline 4 & Width of stipule & 0 . & 1.8 & $\mathrm{~cm}$ \\
\hline 5 & Length of leaf blade & 2 & 9.3 & $\mathrm{~cm}$ \\
\hline 7 & Width of leaf blade & 1.9 & 7.8 & $\mathrm{~cm}$ \\
\hline 8 & Joined portion of the leaf blade & 1.1 & 9.3 & $\mathrm{~cm}$ \\
\hline 6 & Length of the lateral lobe of the leaf blade & 0 & 1.8 & $\mathrm{~cm}$ \\
\hline 9 & Width of the lateral lobe of the leaf blade & 0 & 2.5 & $\mathrm{~cm}$ \\
\hline 10 & Length of the central lobe of the leaf blade & 0 & 3.1 & $\mathrm{~cm}$ \\
\hline 11 & Width of the central lobe of the leaf blade & 0 & 3.4 & $\mathrm{~cm}$ \\
\hline 12 & Length of the petiole glands & 0.02 & 0.15 & $\mathrm{~cm}$ \\
\hline 13 & Width of the petiole glands & 0.02 & 0.1 & $\mathrm{~cm}$ \\
\hline 14 & Length of the petiole & 0.5 & 4 & $\mathrm{~cm}$ \\
\hline 15 & Branch diameter at $10 \mathrm{~cm}$ from the apex & 0.06 & 0.33 & $\mathrm{~cm}$ \\
\hline 16 & Length of smaller bract & 1 & 5.2 & $\mathrm{~cm}$ \\
\hline 17 & Width of smaller bract & 0.4 & 3.5 & $\mathrm{~cm}$ \\
\hline 18 & Length of the larger bract & 1 & 5.5 & $\mathrm{~cm}$ \\
\hline 19 & Width of the larger bract & 0.4 & 4.4 & $\mathrm{~cm}$ \\
\hline 20 & Length of the sepal & 0.6 & 2.6 & $\mathrm{~cm}$ \\
\hline 21 & Width of the sepal & 0.2 & 1.6 & $\mathrm{~cm}$ \\
\hline
\end{tabular}


Table 2. Minimum and maximum values of the multistate and binary characteristics used in the morphological analysis of Passiflora species.

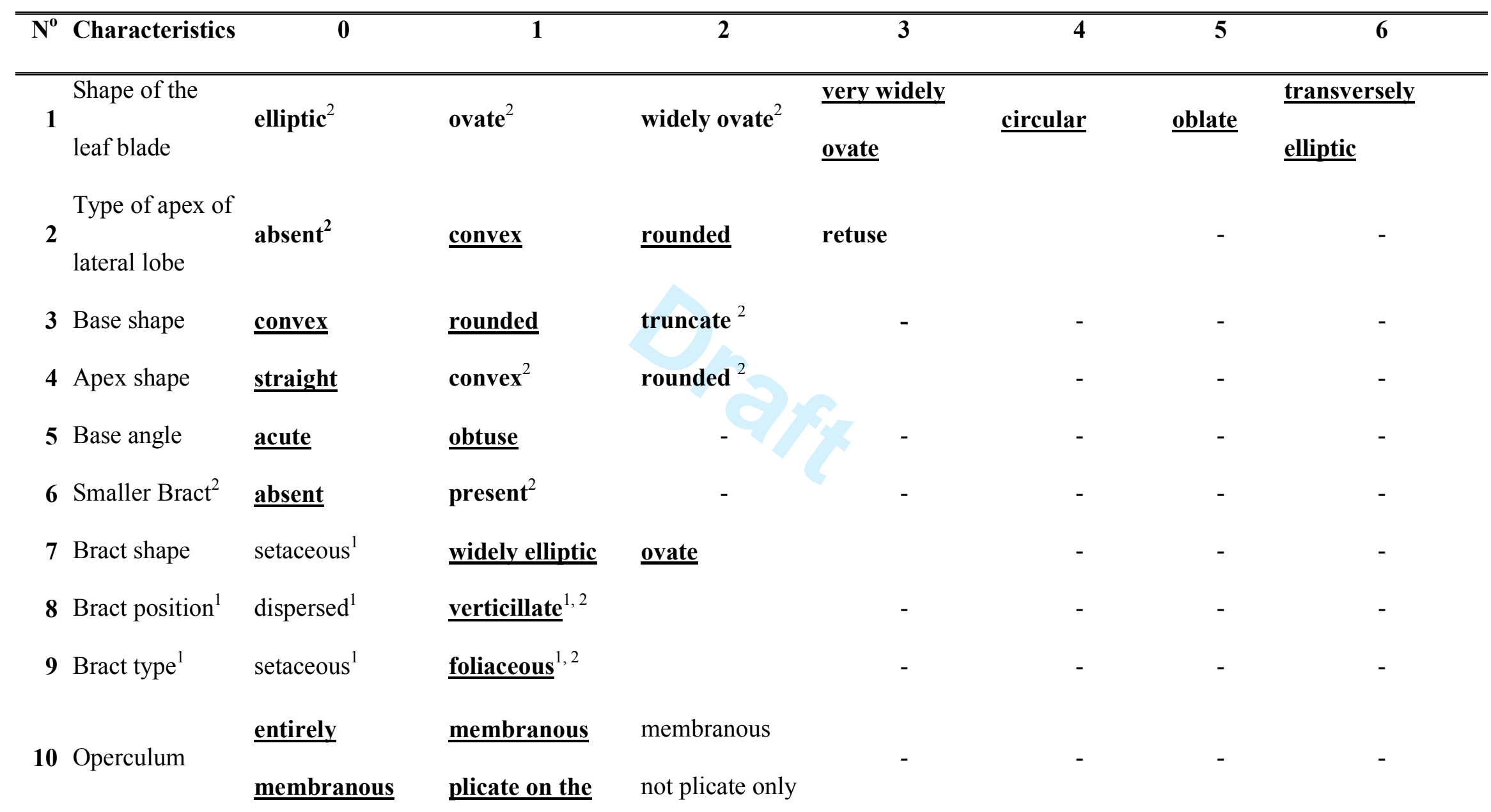




\begin{tabular}{|c|c|c|}
\hline \multirow{3}{*}{ plicate } & base and & on the basis and \\
\hline & filamentous in & filamentous in \\
\hline & the rest & the rest \\
\hline
\end{tabular}

\begin{tabular}{|c|c|c|}
\hline 11 & $\begin{array}{l}\text { Number of basal } \\
\text { veins }^{1}\end{array}$ & $\underline{\mathbf{z}}^{1,2}$ \\
\hline 12 & $\begin{array}{l}\text { First vein } \\
\text { category }^{1}\end{array}$ & $\begin{array}{l}\text { actinodromous } \\
\text { basal }^{1,2}\end{array}$ \\
\hline 13 & $\begin{array}{l}\text { Second vein } \\
\text { category }^{1}\end{array}$ & $\begin{array}{l}\text { brochidodromo } \\
\underline{\mathbf{u s}}^{1,2}\end{array}$ \\
\hline 14 & $\begin{array}{l}\text { Second vein } \\
\text { angle }^{1}\end{array}$ & $\begin{array}{l}\text { smoothly } \\
\text { decreasing } \\
\text { toward base }^{1,2}\end{array}$ \\
\hline 15 & $\begin{array}{l}\text { Second vein } \\
\text { spacing }^{1}\end{array}$ & $\begin{array}{l}\text { increasing } \\
\text { toward base }^{1,2}\end{array}$ \\
\hline 16 & Third vein & alternate \\
\hline
\end{tabular}




\begin{tabular}{|c|c|c|c|}
\hline & category $^{1}$ & percurrent $^{1,2}$ & \\
\hline 17 & $\begin{array}{l}\text { Third vein } \\
\text { course }^{1}\end{array}$ & $\begin{array}{l}\text { exmedially } \\
\text { ramified }^{1,2}\end{array}$ & - \\
\hline 18 & $\begin{array}{l}\text { Third vein angle } \\
\text { to first }{ }^{1}\end{array}$ & $\underline{\text { acute }}^{1,2}$ & - \\
\hline 19 & $\begin{array}{l}\text { Fifth vein } \\
\text { category }\end{array}$ & $\begin{array}{l}\underline{\text { regular }} \\
\text { polygonal } \\
\text { reticulate }^{1,2}\end{array}$ & dichotomizing \\
\hline 20 & Areolation $^{1}$ & $\begin{array}{l}\text { moderately } \\
\text { developed }^{1,2}\end{array}$ & - \\
\hline 21 & Highest order ${ }^{1}$ & $5^{1}$ & $\underline{\mathbf{6}}^{1,2}$ \\
\hline 22 & $\begin{array}{l}\text { Highest } \\
\text { excurrent }{ }^{1}\end{array}$ & $4^{1}$ & $\underline{\mathbf{5}}^{1,2}$ \\
\hline 23 & $\begin{array}{l}\text { Number of sets } \\
\text { of outer corona }^{1}\end{array}$ & $\underline{\mathbf{2}}^{1,2}$ & - \\
\hline
\end{tabular}


24 Shape of the filiform $^{1,2}$

$25 \operatorname{Limen}^{1}$

\section{$\underline{\text { membranaceous }}$}

1,2

${ }^{1}$ - Characteristic not variable or absent in the group P. sidifolia M.Roem (P. actinia Hook., P. elegans Mast. e P. sidifolia M.Roem.) and therefore not considered in the analysis exclusive to this group. Characteristic observed for the group in bold.

${ }^{2}$ - Characteristic not variable or absent only in Passiflora elegans and therefore not considered in the analysis exclusive to it. Characteristic observed for the group underlined. 


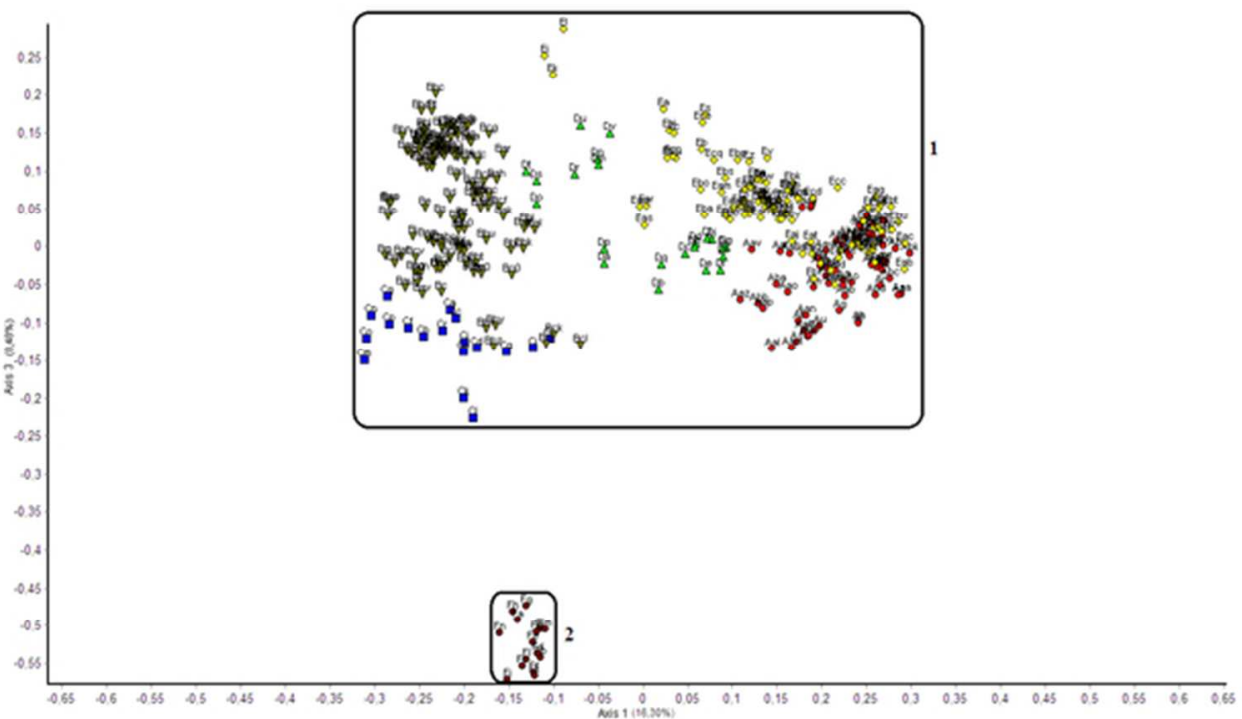

Principal Coordinates Analysis (PCoA) using Gower coefficient and 46 variables showing the distinction between species of the P. sidifolia complex (1 - P. actinia Hook., P. elegans Mast. and P. sidifolia M.Roem.) and $P$. watsoniana Mast (2). Numbers in parentheses on the axes correspond to percentage of variance. $27 \times 16 \mathrm{~mm}(600 \times 600 \mathrm{DPI})$ 

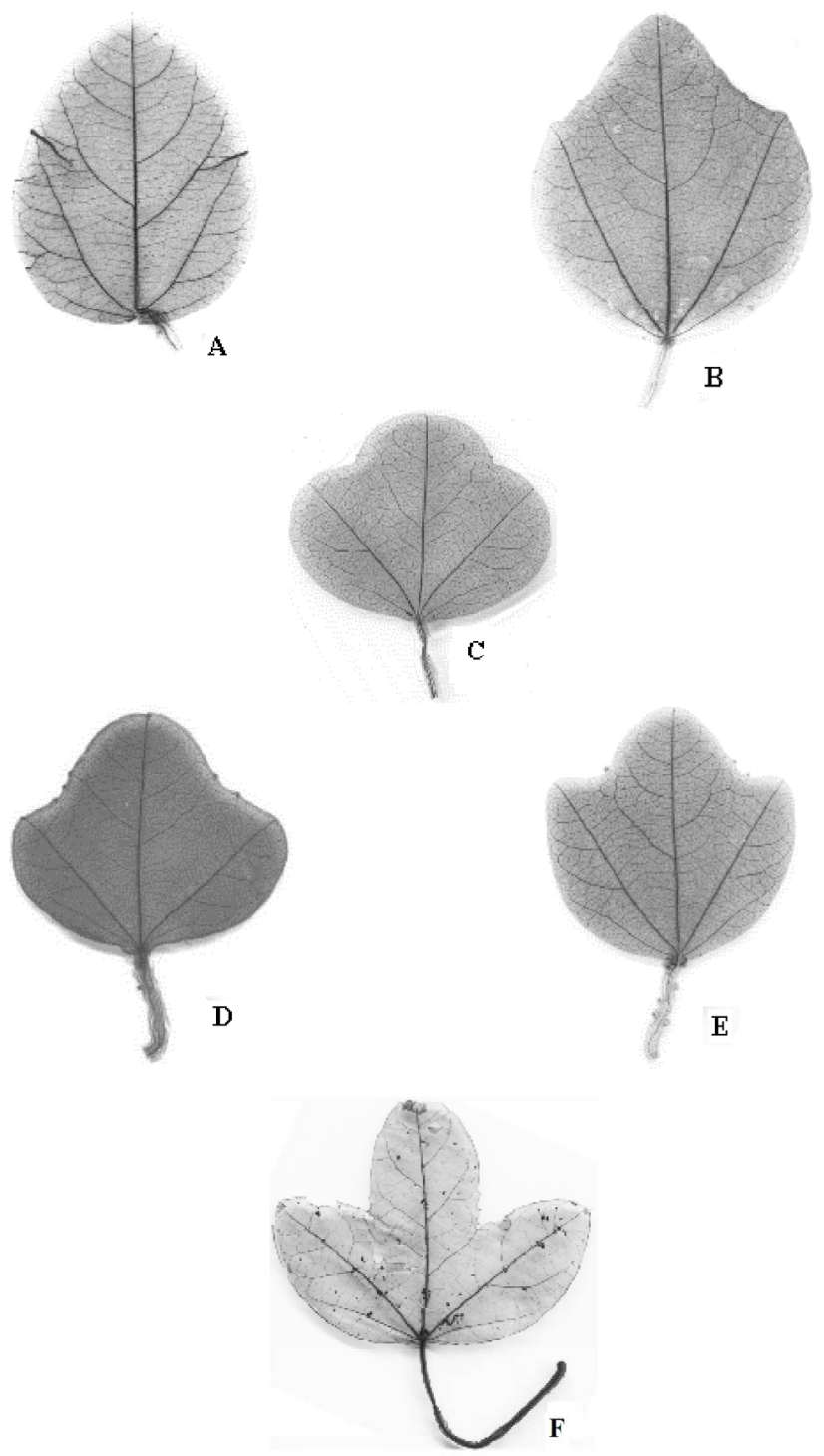

Morphology and venation of leaf blade. A. Passiflora actinia Hook.; B. P. sidifolia M.Roem., C-E. P. elegans Mast. (C. Rio Grande do Sul, D. South Coast of São Paulo state, E. North Coast of São Paulo state) F. P. watsoniana Mast.

$87 \times 146 \mathrm{~mm}(600 \times 600$ DPI $)$ 


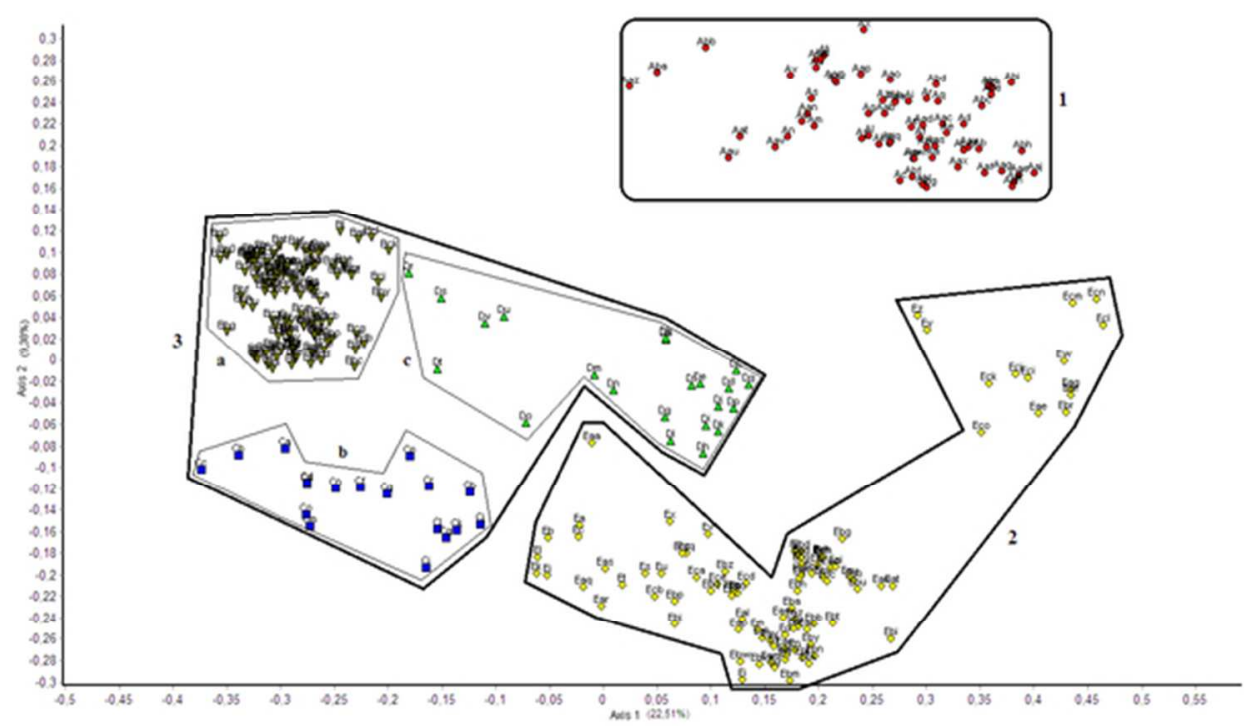

Principal Coordinates Analysis (PCoA) using Gower coefficient and 29 variables of P. elegans Mast. (3) (a RS; b - South Coast of São Paulo state; and c - North Coast of São Paulo state), and of the Passiflora sidifolia complex (1. Passiflora actinia Hook., 2. Passiflora sidifolia M.Roem.). Numbers in parentheses on the axes correspond to percentage of variance.

$27 \times 16 \mathrm{~mm}(600 \times 600 \mathrm{DPI})$ 


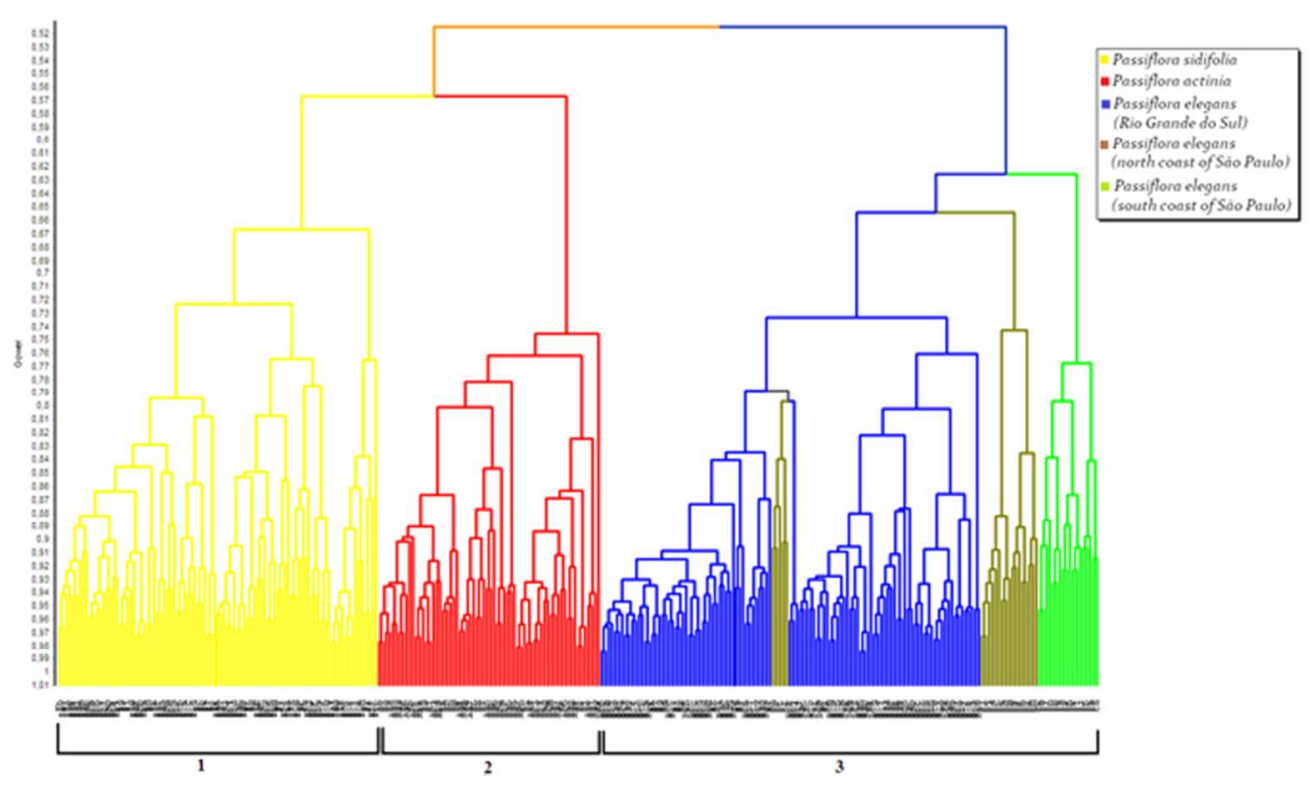

Dendrogram using WPGMA method showing the clusters formed of the Passiflora sidifolia complex ( 1 - P. sidifolia M.Roem.; 2 - P. actinia Hook.; and 3 - P. elegans Mast.). $28 \times 16 \mathrm{~mm}(600 \times 600$ DPI $)$ 


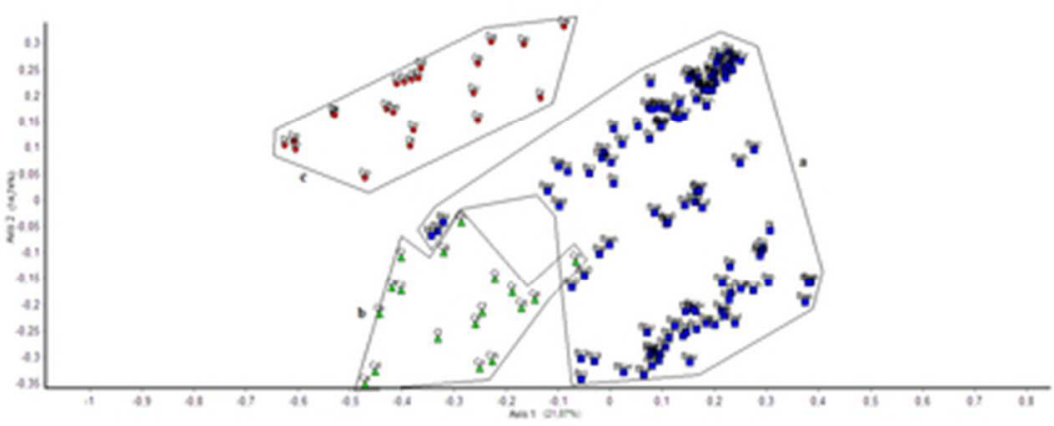

Axes 1 and 2 of the Principal Coordinates Analysis (PCOA) using Gower coefficient and 28 variables showing infraspecific variation of Passiflora elegans Mast. (a - Rio Grande do Sul, b - South Coast of São Paulo state and c- North Coast of São Paulo state). Numbers in parentheses on the axes correspond to percentage of variance.

$18 \times 7 \mathrm{~mm}(600 \times 600 \mathrm{DPI})$ 


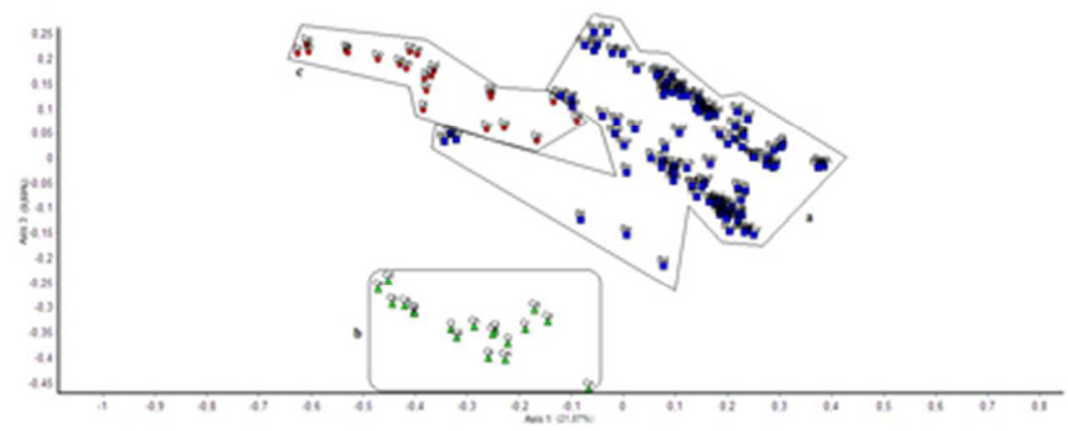

Axes 1 and 3 of the Principal Coordinates Analysis (PCOA) using Gower coefficient and 28 variables showing infraspecific variation of Passiflora elegans Mast. (a - Rio Grande do Sul, b - South Coast of São Paulo state and c- North Coast of São Paulo state). Numbers in parentheses on the axes correspond to percentage of variance.

$18 \times 7 \mathrm{~mm}(600 \times 600 \mathrm{DPI})$ 